\title{
Norway Spruce Seedlings from an Eastern Baltic Provenance Show Tolerance to Simulated Drought
}

\author{
Roberts Matisons ${ }^{1, *}$, Oskars Krišāns ${ }^{1}$, Āris Jansons ${ }^{1}$, Toms Kondratovičs ${ }^{1}$, Didzis Elferts ${ }^{1,2}$ (D) \\ and Gederts Ievinsh ${ }^{2}$ \\ 1 Latvian State Forest Research Institute 'Silava', 111 Rigas str., LV-2169 Salaspils, Latvia; \\ oskars.krisans@silava.lv (O.K.); aris.jansons@silava.lv (Ā.J.); toms.kondratovics@silava.lv (T.K.); \\ didzis.elferts@lu.lv (D.E.) \\ 2 Faculty of Biology, University of Latvia, Jelgavas str. 1, LV-1010 Riga, Latvia; gederts.ievins@lu.lv \\ * Correspondence: robism@inbox.lv; Tel.: +371-29789581
}

check for

updates

Citation: Matisons, R.; Krišāns, O.; Jansons, Ā.; Kondratovičs, T.; Elferts, D.; Ievinsh, G. Norway Spruce Seedlings from an Eastern Baltic Provenance Show Tolerance to Simulated Drought. Forests 2021, 12, 82. https://doi.org/10.3390/ f12010082

Received: 21 December 2020 Accepted: 11 January 2021 Published: 14 January 2021

Publisher's Note: MDPI stays neutral with regard to jurisdictional clai$\mathrm{ms}$ in published maps and institutional affiliations.

Copyright: () 2021 by the authors. Licensee MDPI, Basel, Switzerland. This article is an open access article distributed under the terms and conditions of the Creative Commons Attribution (CC BY) license (https:// creativecommons.org/licenses/by/ $4.0 /)$.

\begin{abstract}
In Northern Europe, an increase in heterogeneity of summer precipitation regime will subject forests to water deficit and drought. This is particularly topical for Norway spruce (Picea abies Karst.), which is a drought sensitive, yet economically important species. Nevertheless, local populations still might be highly plastic and tolerant, supporting their commercial application. Accordingly, the tolerance of Norway spruce seedlings from an Eastern Baltic provenance (western part of Latvia) to artificial drought according to soil type was assessed in a shelter experiment. To simulate drought, seedlings were subjected to reduced amounts $(0 \%, 25 \%, 50 \%, 75 \%$, and $100 \%)$ of naturally occurring precipitation (irrigation intensity). Three soil types (oligotrophic mineral, mesotrophic mineral, and peat) were tested. Seedling height, chlorophyll $a$ concentration, and fluorescence parameters were measured. Both growth and photochemical reactions were affected by the irrigation intensity, the effect of which experienced an interacted with soil type, implying complex controls of drought sensitivity. Seedlings were more sensitive to irrigation intensity on mesotrophic mineral soil, as suggested by growth and photosynthetic activity. However, the responses were nonlinear, as the highest performance (growth and fluorescence parameters) of seedlings occurred in response to intermediate drought. On peat soil, which had the highest water-bearing capacity, an inverse response to irrigation intensity was observed. In general, fluorescence parameters were more sensitive and showed more immediate reaction to soil water deficit than concentration of chlorophyll on mesotrophic mineral and peat soils, while the latter was a better indicator of seedling performance on oligotrophic soil. This indicated considerable plastic acclimation and hence tolerance of seedlings from the local Norway spruce population to drought, though drought sensitivity is age-dependent.
\end{abstract}

Keywords: Picea abies; intra-annual height growth; irrigation manipulation; local tree population; photosynthetic activity

\section{Introduction}

The projected climate-driven shifts in vegetation zones imply considerable changes in forest composition in Northern Europe by the end of the 21st century [1], which are expected to result in substantial economic consequences [2]. The accelerating rate of climatic changes suggests that natural adaptation of tree populations is lagging behind and proactive management is necessary to maintain forest sustainability [3]. Nevertheless, tree populations can still express high adaptability to changing conditions, at least in terms of growth performance, if smartly managed [3-5]. Therefore, uncertainties about the utilization of local genetic material for forest regeneration and further application of conservative management strategies still remain [6].

Warming and an extension of the vegetation period appears advantageous for growth of boreal and hemiboreal forests [7]; however, increased temperature facilitates evapotranspiration [8]. Furthermore, water deficit conditions are projected to intensify due to 
increasing heterogeneity of the precipitation regime [9]. This would cause water deficit conditions to affect tree growth in ecosystems not considered as water limited, such as boreal and hemiboreal forests $[10,11]$. Continuous water deficit also alters allocation of assimilates, affecting biochemical pathways, growth [12,13], and wood structure [14], thus calling into question the plasticity of a species/population. Woody biomass accumulation is lagged relative to increment, hence the periods crucial for the productivity of stands extend beyond the periods of growth [15]. Still, meristematic tissues in trees can maintain their properties during drought-induced dormancy, ensuring the potential for growth recovery [16]. Accordingly, the adaptability of trees to a variable moisture regime and the application of climate-smart management appear to be key issues for the sustainability of forests $[17,18]$.

Among the commercially important tree species in Northern Europe, Norway spruce (Picea abies Karst.) is highly sensitive to water deficit $[14,16,19,20]$, which also increases biotic risks [21-23]. Recent droughts have caused massive diebacks of weakened Norway spruce due to pest outbreaks in Central Europe [21]. Young trees are also sensitive to soil water shortage, which increases their mortality due to limited rooting depth [24,25]; though (meta) populations can differ in susceptibility to water deficit [26]. In this respect, soil type modulates the sensitivity of trees to water deficit, thus diversifying the susceptibility of spruce forests to droughts [27]. Accordingly, information about the responsiveness of local populations to water stress under diverse growing (soil) conditions aids assessment of their growth potential under changing climatic conditions $[3,17,26]$.

Under a changing climate, early warning systems that monitor the health condition of forests can aid decisionmakers in operatively adjusting forest management, thereby helping to reduce losses due to unfavourable conditions [28-30]. For such a purpose, remote sensing is a highly effective tool for the census of vast areas [29,31] via extrapolation of the emission of refracted light from foliage, which represents the concentration of chlorophyll $a$ (CHL) and other foliage pigments [32]. Such a census exploits the relationships between the concentration of phytochromes and stress, thus allowing for an assessment of the physiological state of trees $[33,34]$; though such relationships might differ among species and/or populations, as well as according to the edaphic conditions [5,35].

Physiological responses of plants to water stress have been a sustained subject of inquiry [36-39], with photosynthesis-related parameters gaining much attention due to high sensitivity $[40,41]$. Analysis of photosynthetic gas exchange has considerable limitations regarding drought stress due to stomatal closure [42]. Therefore, chlorophyll $a$ fluorescence describing the characteristics of captured light energy transfer in a leaf's photosystem has emerged as a useful approach for field studies [36,43]. In Norway spruce, however, CHL has been shown to be a less sensitive proxy for drought stress due to the plastic adaptation of physiological processes $[5,24]$, hence fluorescence parameters might be more informative proxies $[35,44]$. Considering provenance-specific responses of trees to environmental factors [17,18,26,35], local (provenance region) information is necessary for a more accurate census of the health and stresses of Norway spruce stands.

The aim of this study was to assess the effect of simulated drought on the growth and photosynthetic performance of eastern Baltic Norway spruce seedlings on different soils under hemiboreal conditions. We hypothesised that growth and florescence show a marked response to water deficit, while the reaction of CHL is delayed and occurs only under severe water stress conditions.

\section{Materials and Methods}

\subsection{Experimental Setup}

An open-field experiment was conducted in the summer of 2015 in the central part of Latvia $\left(56^{\circ} 37^{\prime} \mathrm{N} ; 24^{\circ} 29^{\prime} \mathrm{E}\right)$. The climate of the study site can be described as temperate and moist continental. The mean annual temperature ( \pm st. dev.) during 1986-2015 was $7.2 \pm 0.7^{\circ} \mathrm{C}$, with July being the warmest $\left(18.2 \pm 1.2^{\circ} \mathrm{C}\right)$ and February being the coldest $\left(-2.6 \pm 3.2^{\circ} \mathrm{C}\right)$ months, according to data from the gridded datasets (CRU TS) [45]. 
The mean annual precipitation was $659 \pm 75 \mathrm{~mm}$; the highest monthly precipitation fell during the summer months (May-September, $70 \pm 25 \mathrm{~mm}$ ). According to the data from a local meteorological station located $<30 \mathrm{~m}$ away from the site of the experiment, during the experiment (June-August), the daily mean temperature was $17.3 \pm 2.7^{\circ} \mathrm{C}$, which is comparable with the long-term means (Figure 1). The absolute minimum and maximum recorded hourly temperatures were $4.3^{\circ} \mathrm{C}$ and $32.8^{\circ} \mathrm{C}$, respectively. The monthly amount of precipitation was $35 \mathrm{~mm}$, which is approximately half the long-term mean. Most of precipitation fell during the first part of the experimental period; the precipitation-free periods were up to 11 days long. Air humidity, as described by the atmospheric vapour pressure deficit (VPD), was low during most of the period, yet rapidly increased during the last two weeks.
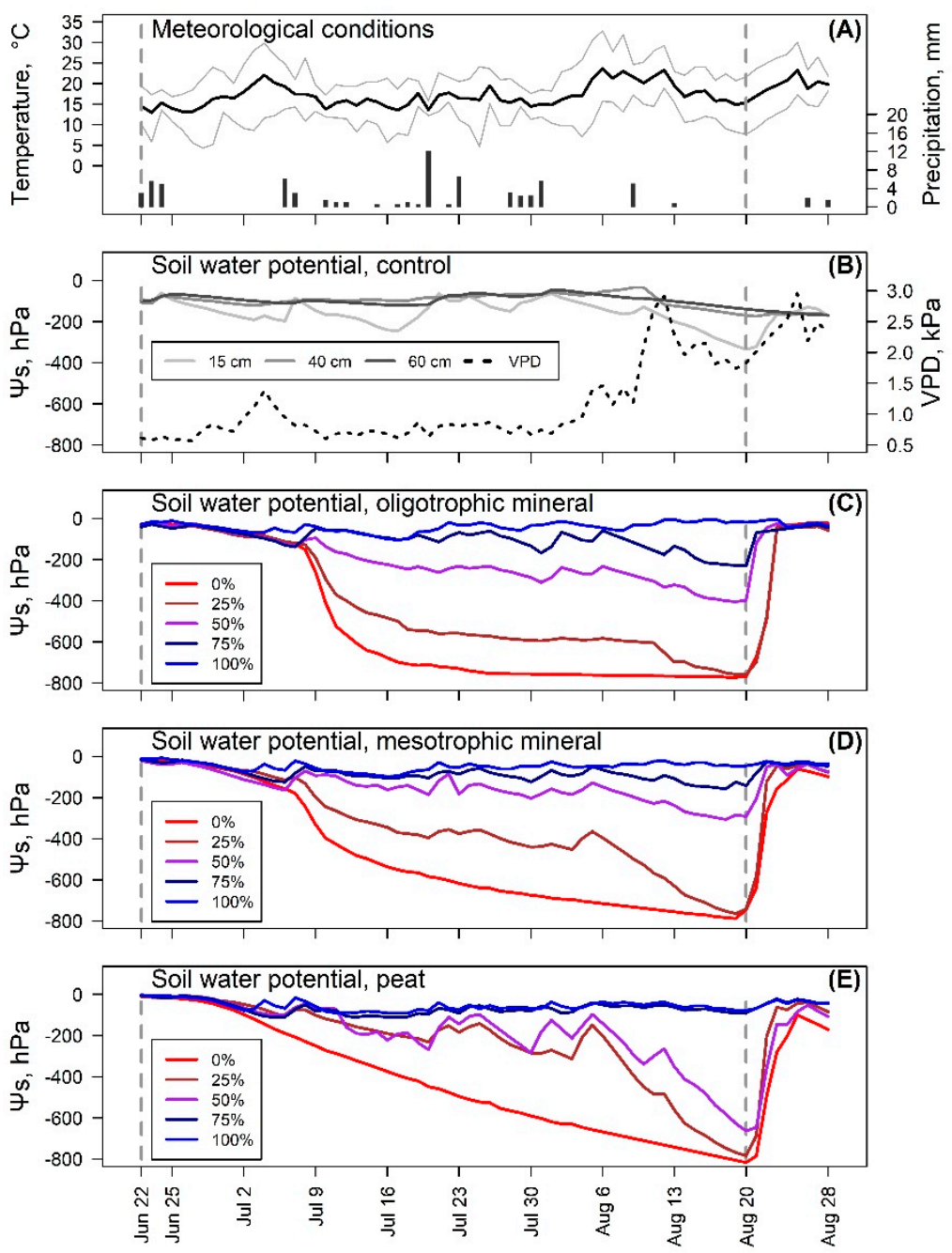

Figure 1. Meteorological and soil moisture conditions during the experimental period. In (A), daily mean (bold black line), minimum and maximum (grey lines) temperature and precipitation (bars) are shown. In (B), atmospheric vapour pressure deficit (dotted line) and soil water potential ( $\Psi$ s) at three soil depths is shown. Panels (C-E) show the soil water potential in the shelter pots filled with oligotrophic, mesotrophic, and peat forest soil according to the irrigation intensity. The vertical dotted lines denote the initiation and termination of precipitation manipulation.

To study the effect of drought on the third-year seedlings of Norway spruce, an automated mobile polycarbonate shelter (transparency $\geq 81 \%$ ) equipped with a rain sensor was used to intercept natural precipitation (precipitation manipulation). Bare-rooted seedlings of Norway spruce were acquired from a local nursery. The plantlets were raised from the seed material obtained from a seed orchard consisting of clones of approximately 60 plus 
trees originating from the local provenance region (western part of Latvia; $56.4-57.6^{\circ} \mathrm{N}$, 21.0-23.5 E). In mid-April 2015, seedlings were planted in $4.5 \mathrm{~L}$ free-drained plastic containers $(0.2 \mathrm{~m} \times 0.2 \mathrm{~m}$ opening $)$ and placed on an elevated platform to eliminate the effect of soil moisture. Three types of substrate were employed for the representation of the most common forest types used for Norway spruce forestry in Latvia.

The substrates were collected in forest stands within the study region, where according to forest inventories, land use (forests) has been constant during the last 100 years. Two types of mineral soil and a peat soil were used. Oligotrophic sandy soil was collected in a Cladinoso-callunosa forest stand, mesotrophic silt soil was acquired in a Hylocomiosa stand, and peat soil was collected in a mesotrophic meliorated peatland Myrtillosa turf. mel. stand (according to local forest classification by Bušs [46]). The top $20 \mathrm{~cm}$ of soil were collected. Prior to the planting, soil was homogenised. Detailed information on the chemical composition of the substrates is shown in Table 1.

Table 1. Detailed characteristics of the studied soil substrates.

\begin{tabular}{cccc}
\hline & Oligotrophic & Mesotrophic & Peat \\
\hline Parent material & Sand & Silty sand & Organic \\
Reaction, pH & $6.64 \pm 0.13$ & $6.48 \pm 0.09$ & $2.74 \pm 0.05$ \\
N total., g kg & 0.1 & $0.86 \pm 0.09$ & $18.51 \pm 1.24$ \\
C total., g kg & $1.16 \pm 0.04$ & $8.67 \pm 1.3$ & $499.33 \pm 15.95$ \\
$\mathrm{C} / \mathrm{N} \mathrm{ratio}^{-1}$ & - & $12.32 \pm 11.18$ & $27.08 \pm 2.35$ \\
$\mathrm{~S}, \mathrm{mg} \mathrm{kg}^{-1}$ & - & $254.13 \pm 11.4$ & $2510.09 \pm 348.31$ \\
$\mathrm{P}, \mathrm{mg} \mathrm{kg}^{-1}$ & $167.41 \pm 4.07$ & $71.6 \pm 3.71$ & $71.93 \pm 2.65$ \\
$\mathrm{~K}, \mathrm{mg} \mathrm{kg}^{-1}$ & $14.33 \pm 2.67$ & $0.99 \pm 0.32$ & $0.55 \pm 0.06$ \\
$\mathrm{Mg}, \mathrm{g} \mathrm{kg}^{-1}$ & $0.52 \pm 0.02$ & $6.3 \pm 2.32$ & $9.01 \pm 0.84$ \\
$\mathrm{Ca}, \mathrm{g} \mathrm{kg}^{-1}$ & $4.15 \pm 0.25$ & $0.64 \pm 0.01$ & $0.55 \pm 0.04$ \\
$\mathrm{Fe}, \mathrm{g} \mathrm{kg}^{-1}$ & $0.13 \pm 0.01$ & $121.42 \pm 10.25$ & $19.4 \pm 3.41$ \\
$\mathrm{Mn}, \mathrm{mg} \mathrm{kg}^{-1}$ & $32.06 \pm 2.41$ & $3.46 \pm 1.02$ & $9.06 \pm 3.06$ \\
$\mathrm{Zn}, \mathrm{mg} \mathrm{kg}^{-1}$ & $1.06 \pm 0.28$ & $3.71 \pm 0.57$ & $4.04 \pm 1.11$ \\
$\mathrm{Cu}, \mathrm{mg} \mathrm{kg}^{-1}$ & $1.00 \pm 0.38$ & & \\
\hline
\end{tabular}

Until the initiation of the precipitation manipulation, seedlings were irrigated abundantly (avoiding soil water deficit) to ensure the establishment and development of their root system. Precipitation manipulation was initiated on 22 June 2015, when elongation (height) growth of the seedlings was culminating. To simulate drought of different intensities, natural precipitation was intercepted by the automated mobile shelter. Once per four days, seedlings were supplied with local groundwater, providing $0 \%, 25 \%, 50 \%$, $70 \%$, and $100 \%$ of the natural precipitation occurring during the relevant four-day period (irrigation intensity treatments; IRIN), using a bucket drip irrigation system. Precipitation manipulation was terminated on 20 August 2015, and trees were re-watered abundantly thereafter to evaluate their survival and recovery after the treatment. For the control, next to the shelter (in an unsheltered area), the top layer $(22 \mathrm{~cm}$ ) of local soil was replaced with mesotrophic forest soil (typical for commercial spruce stands), which was separated by a geotextile, thus allowing natural soil moisture to ascend, yet preventing roots to penetrate deeper soil horizons. Seedlings were planted directly in the soil, maintaining the same spacing $(0.2 \mathrm{~m} \times 0.2 \mathrm{~m})$ as the potted seedlings. Each of the 15 treatments and the control were represented by 40 seedlings, thus, in total, 640 seedlings were used.

\subsection{Measurements}

The height of each seedling (stem) was measured weekly using a measuring tape with the precision of one millimetre from the initiation of the precipitation manipulation until the cessation of elongation growth at the end of July. For each treatment combination and the control, five random seedlings were selected for the measurements of chlorophyll $a$ florescence and soil water potential ( $\Psi$ s) throughout the experiment. Starting on June 25, the chlorophyll $a$ fluorescence induction curve, which represents the total photochemical 
activity [36,47], was measured with a Handy PEA (Hansatech Instruments, Norfolk, UK) continuous fluorometer and CHL was estimated with a CCM-300 chlorophyll meter (OptiSciences, Hudson, NH) at weekly intervals. Height and florescence measurements were synchronous. Three measurements per tree were performed on the second-year needles on the same uppermost branches of the seedlings. The measurements were finalized with the termination of precipitation manipulation. The total performance index (PI), which aggregates the relative expression of the photochemical performance of electron transfer from water to NADPH (concentration of reaction centres, light and dark reactions) [36,47], $\mathrm{F}_{\mathrm{v}} / \mathrm{F}_{0}$, and $\mathrm{CHL}$ were acquired as the proxies of fluorescence [5].

To control for changes in soil moisture, two random pots per treatment combination (soil and IRIN) were equipped with T8 tensiometers (UMS GmbH, Frankfurt am Main, DE). In the control, three tensiometers were installed at the depth of $15 \mathrm{~cm}$. Additionally, six tensiometers were installed next to the control treatment at the depth of 40 and $60 \mathrm{~cm}$ in order to control for $\Psi$ s in the deeper horizons. Meteorological conditions were monitored using a Davis Wireless Vantage Pro2 (Davis Instruments, Hayward, CA) portable automatic weather station, which was located at $5 \mathrm{~m}$ away from the shelter.

\subsection{Data Analysis}

Considering that the planted seedlings differed in height, relative growth rate (RGR) was calculated as a proxy for intra-annual height increment during the studied period (with respect to the initial height of seedling). To quantify the effects of the studied treatments on height growth (RGR) patterns, nonlinear mixed logistic regression [48] was fit as follows:

$$
\mathrm{RGR}=\frac{\alpha}{1+\beta e^{(\mathrm{k} * \mathrm{~A})}}+\left(I_{\alpha, \beta, k}\right)+\left(S_{\alpha, \beta, k}\right)+\varepsilon,
$$

where RGR refers to relative growth rate, $\alpha$ refers to asymptote parameter, $\beta$ refers to the displacement (lag) parameter, $k$ refers to the growth cessation rate parameter, A refers to time since culmination of height growth (in weeks), and $\left(I_{\alpha, \beta, k}\right)$ and $\left(S_{\alpha, \beta, k}\right)$ are the random effects of experimental treatments (IRIN and soil, respectively) affecting each of the model terms.

Treatments were considered as the statistical unit for this analysis. Model parameters for each treatment combination were extracted from the model and compared using ANOVA (the interaction of treatments was not assessed due to the limited size of the dataset). A simple ANOVA was also used to assess the effect of experimental treatments on the total relative increment. Pearson correlation analysis was used to assess the linear linkage between the environmental variables.

Linear mixed effects models were used to analyse the effect of the experimental treatments on the florescence proxies, as well as on the RGR, throughout the experimental period. The model in the general form was as follows:

$$
\mathrm{y}_{i j}=\mu+\mathrm{I}+\mathrm{S}+\mathrm{I} \times \mathrm{S}+t_{i}+V P D_{i}+\Psi_{s j}+\mathrm{A}+\left(\text { tree }_{j}\right)+\varepsilon_{i j},
$$

where $\mu$ refers to the overall mean, I refers to the fixed effect of IRIN (five levels), $S$ refers to the fixed effect of soil type (three levels), I $\times \mathrm{S}$ refers to the fixed effect of IRIN by soil type interaction, $t_{i}, V P D_{i}$, and $\Psi s_{j}$ refer to mean temperature, atmospheric vapour pressure deficit, and $\Psi$ s in the pots for the seven-day period prior to measurements (as covariates), respectively, A refers to the time since growth peak (in weeks), and (tree ${ }_{j}$ ) is the random effect of individual tree.

Time was included in the model to account for trends in the data. Models were fit using the restricted maximum likelihood approach. The maximum likelihood approach with the type II Wald $\chi^{2}$ test was used to estimate the strength of the effects of the studied treatments. The control treatment was not included in the calculations, as it implied differences in soil temperature, yet was used for illustrative purpose. The explanatory 
variables were checked for collinearity using the variance inflection factor. Data analysis was conducted in program R v. 4.0.2 [49], using package "lme4" [50].

\section{Results}

\subsection{Soil Moisture}

The IRIN had a proportional effect on $\Psi$ s, which showed clear differences among the studied soil types (Figure 1). In the mineral soils, particularly oligotrophic sandy soil, under the $0 \%$ and $25 \%$ IRIN, $\Psi$ s showed a rapid drop approximately 12 days after the initiation of precipitation manipulation. Under the $75 \%$ IRIN, the decrease in $\Psi$ s was slight $(\geq-200 \mathrm{hPa})$. The $100 \%$ IRIN was sufficient to maintain high $\Psi \mathrm{s}(\geq-120 \mathrm{hPa})$.

The drying out of peat soil under the $0 \%$ IRIN proceeded gradually, reaching the minimum values of approximately $-800 \mathrm{hPa}$ at the end of the experiment (Figure 1). Under the $25 \%$ and $50 \%$ irrigation intensities, $\Psi$ s showed only a slight decrease (reaching approximately $-280 \mathrm{hPa}$ ) until August 6, followed by a rapid drop until the end of the experiment. Under $75 \%$ and $100 \%$ IRINs, $\Psi$ s practically remained at the initial levels.

Peat soil showed the clearest short-time fluctuations of $\Psi$ s, coinciding with irrigation and variations in VPD. Still, only negligible short-term fluctuations occurred under the $0 \%$ IRIN, irrespective of soil type. Slight fluctuation occurred under the control treatment in the top layer $(15 \mathrm{~cm})$, where $\Psi$ s reached $-335 \mathrm{hPa}$ around mid-August, following the increase in VPD. In the deeper soil layers $(40$ and $60 \mathrm{~cm})$, $\Psi$ s was mostly high $(\geq-175 \mathrm{hPa})$, indicating sufficient water supply.

\subsection{Seedling Growth}

Most of the seedlings ( $87.4 \%$ ) survived the experiment, while $0 \%$ irrigation on the mineral soils caused most of the mortality (all seedlings in these treatment combinations died by the end of the experiment). The mean height ( $\pm 95 \%$ confidence interval) of the studied third-year seedlings of Norway spruce increased from to $47.7 \pm 7.2$ to $58.7 \pm 6.9 \mathrm{~cm}$, resulting in an intermediate relative increment of $23.1 \%$. Soil type, and particularly IRIN, had a significant $(p<0.001)$ effect on the total relative increment (Table 2). However, the significant interaction $(p<0.05)$ between the treatments implied a varying effect of irrigation among soil types.

Table 2. The ANOVA (type II tests) table of the total relative increment of the studied third-year seedlings of Norway spruce according to soil type and irrigation intensity.

\begin{tabular}{ccccc}
\hline & Sum of Squares & $d f$ & $\boldsymbol{F}$-Value & $p$-Value \\
\hline Soil type & 0.177 & 3 & 9.7 & $<0.001$ \\
Irrigation intensity & 0.109 & 1 & 18.0 & $<0.001$ \\
Soil type by irrigation intensity interaction & 0.040 & 2 & 3.4 & 0.04 \\
Residuals & 4.174 & 686 & & \\
\hline
\end{tabular}

In both oligotrophic and, particularly, mesotrophic mineral soils, the highest relative increment was observed for trees subjected to the intermediate IRINs $(75 \%, 50 \%$, and $25 \%$; Figure 2). The lowest relative increment formed under the $0 \%$ IRIN on mesotrophic soil, yet, contrastingly, under the highest IRIN on oligotrophic soil. Surprisingly, on peat soil, relative increment was inversely related to IRIN, with the highest values observed when receiving $0 \%$ and $25 \%$ of irrigation. Under the higher IRINs ( $\geq 50 \%$ ), relative increment was the lowest, ranging 19.5-22.3\%. Regarding the individual effect of soil type, the highest relative increment was observed for seedlings growing on mesotrophic soil, and the lowest was observed for seedlings growing on peat soil (Figure 2). 


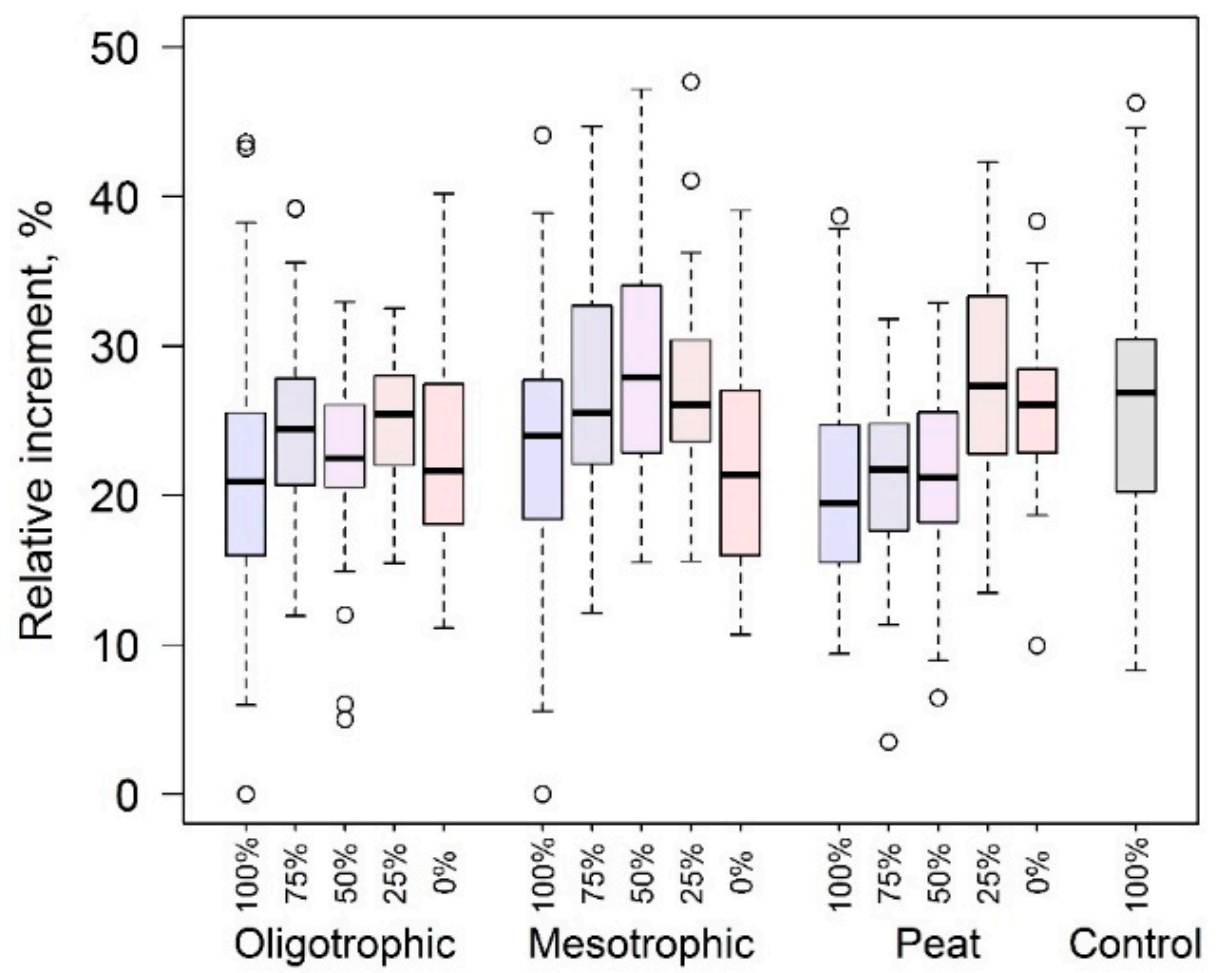

Figure 2. Relative increment of the third-year seedlings of Norway spruce according to the studied soil types and irrigation intensities (proportion of natural precipitation) at the end of experiment. Lines show medians, boxes represent the first and third quartiles, whiskers mark the range (not exceeding $150 \%$ of the interquartile distance), and circles denote outliers of the datasets.

The intra-annual growth patterns were mainly affected by IRIN, as suggested by the differences in the parameters of the fitted logistic growth functions (Table 3). A stronger effect of IRIN was observed for $\beta$ and, particularly, $k$ parameters. The displacement parameter $(\beta)$ was mostly proportional to the IRIN, while the growth rate parameter $(k)$ showed an inverse relationship (Figure 3), implying that water deficit resulted in a faster cessation of shoot elongation (Figure 4A-C). Soil type had a marginal effect $(p=0.048)$ on the growth rate parameter (Table 3), which decreased with increasing soil fertility (Figure 3), implying slower growth, which, however, ceased later on more fertile soil (Figure $4 \mathrm{~A}-\mathrm{C}$ ). The maximum weekly RGR (asymptote, $\alpha$ ) appeared unaffected by the studied treatments (Table 3), though it varied among the treatment combinations. Under the control treatment, seedlings that received ground water and were subjected to a different soil temperature regime (not shown) ceased growth approximately two weeks later (Figure $4 \mathrm{~A}-\mathrm{C}$ ) and formed larger relative increments (Figure 2).

Table 3. The ANOVA (type II tests) table of the three parameters of logistic growth function (growth asymptote, displacement, and growth rate) of height growth cessation (after peak) of the studied third-year Norway spruce seedlings according to soil type and irrigation intensity. A single function was fit for each treatment. The interaction terms were not calculated due to limitations of the dataset.

\begin{tabular}{ccccc}
\hline & Degree of Freedom & Sum of Squares & $\boldsymbol{F}$-Value & $p$-Value \\
\hline & \multicolumn{1}{c}{ Asymptote parameter $(\boldsymbol{\alpha})$} & & \\
Soil type & 2 & $1.25 \cdot 10^{-6}$ & 1.88 & 0.21 \\
Irrigation intensity & 4 & $3.05 \cdot 10^{-6}$ & 2.29 & 0.15 \\
Residual & 8 & $2.67 \cdot 10^{-6}$ & & \\
\hline
\end{tabular}


Table 3. Cont.

\begin{tabular}{ccccc}
\hline & Degree of Freedom & Sum of Squares & F-Value & $p$-Value \\
\hline & Displacement (lag) parameter $(\boldsymbol{\beta})$ & & \\
Soil type & 2 & $4.73 \cdot 10^{-6}$ & 3.48 & 0.08 \\
Irrigation intensity & 4 & $1.69 \cdot 10^{-5}$ & 6.21 & 0.01 \\
Residual & 8 & $5.43 \cdot 10^{-6}$ & & \\
& Growth rate parameter $(\boldsymbol{k})$ & & \\
Soil type & 2 & $4.17 \cdot 10^{-7}$ & 4.33 & 0.048 \\
Irrigation intensity & 4 & $1.35 \cdot 10^{-6}$ & 7.01 & $<0.01$ \\
Residual & 8 & $3.85 \cdot 10^{-7}$ & & \\
\hline
\end{tabular}
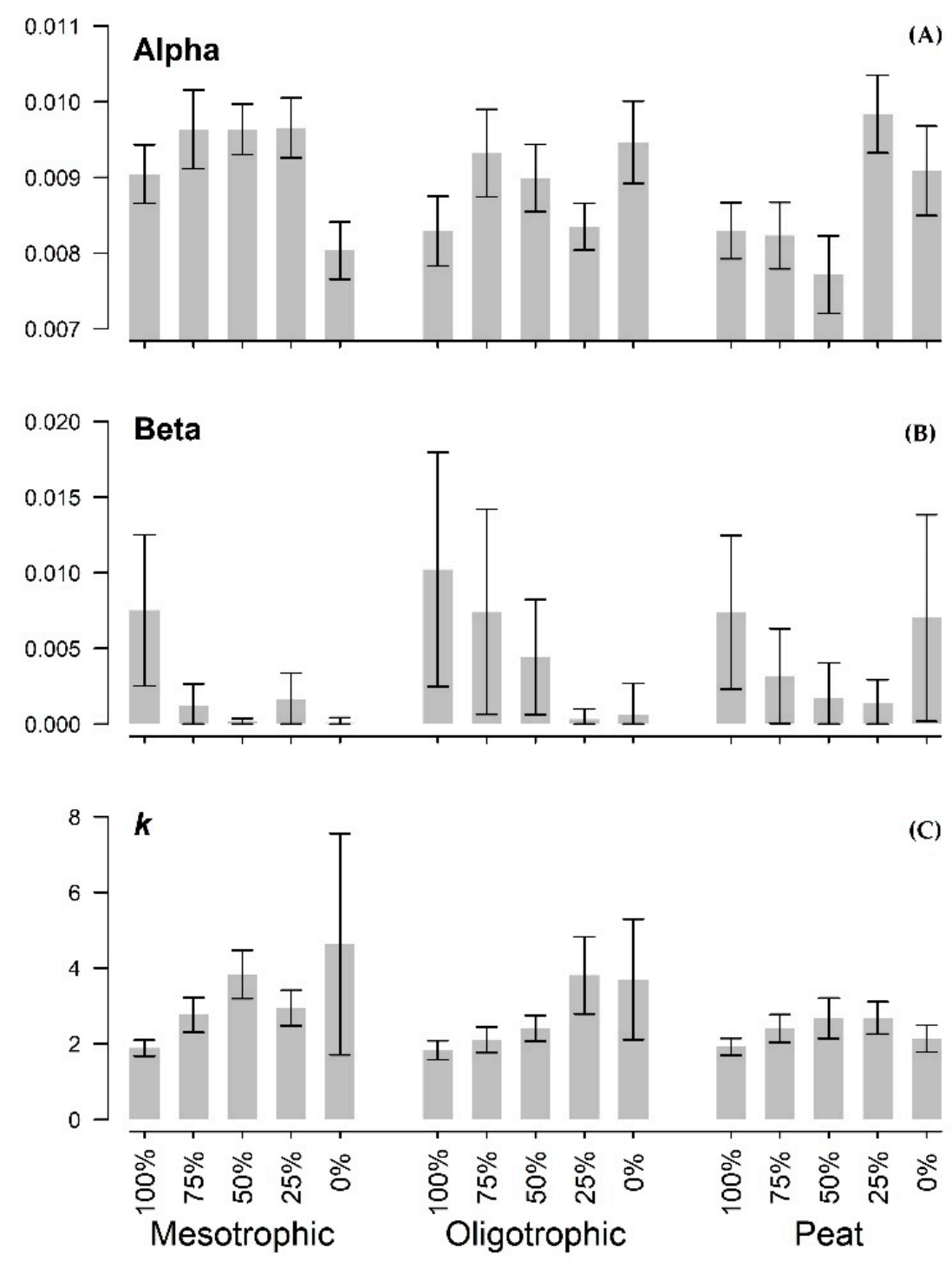

Figure 3. The asymptote (alpha) (A), displacement (beta) (B), and growth rate $(k)(\mathbf{C})$ parameters of the logistic regression of the relative increment of the third-year seedlings of Norway spruce according to soil type and irrigation intensity (proportion of natural precipitation). The whiskers indicate the standard errors of the estimates. 


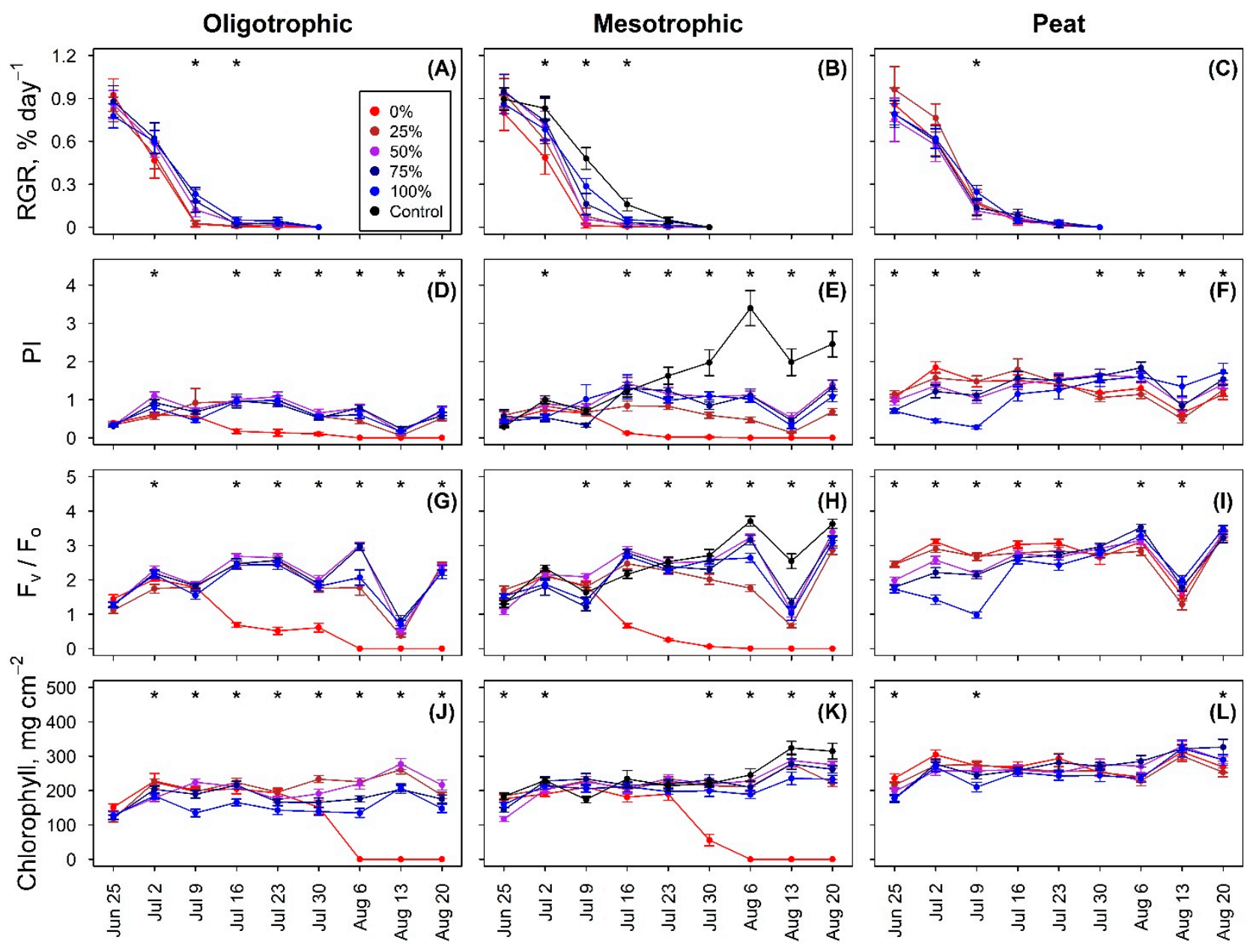

Figure 4. The intra-annual dynamics of relative growth rate (RGR, A-C), photosynthetic performance index $(\mathrm{PI}, \mathrm{D}-\mathrm{F}), \mathrm{F}_{\mathrm{v}} / \mathrm{F}_{0}$ ratio $(\mathrm{G}-\mathrm{I})$, and chlorophyll concentration $(\mathrm{J}-\mathrm{L})$ in the second-year needles of the third-year seedlings of Norway spruce according to soil type and irrigation intensity (proportion of natural precipitation; indicated by colours). The whiskers denote $95 \%$ confidence intervals. The asterisks above the points indicate significant $(p$-value $<0.05)$ differences among the irrigation intensities (the control was excluded from the calculation).

The tree-level analysis indicated that weekly RGR was affected by VPD, which was not detected for the growth function parameters, as well as by the interaction of the studied treatments (Table 4). The interaction highlighted the differences in growth plasticity on the mineral and organic soils, with the responses being more plastic on mineral soils than on peat (Figure 4A-C). However, the differences (proportional) in weekly RGR according to IRIN were significant only for a few weeks, when irrigation was provided after a precipitation-free period (Figure 1). The variance in weekly RGR associated with the random effect of individuals was low (Table 4), implying a common response of seedlings.

Table 4. The effect ( $\chi^{2}$ values) of soil type, irrigation intensity, air temperature, atmospheric vapour pressure deficit, and soil water potential on weekly relative growth rate, photosynthetic performance index, $\mathrm{F}_{\mathrm{v}} / \mathrm{F}_{0}$ ratio, and chlorophyll concentration in the second-year needles of the third-year seedlings of Norway spruce. The asterisks denote statistical significance ( $p$-values) of the effects: ${ }^{*}<0.05,{ }^{* *}<0.01$, and ${ }^{* *}<0.001 . d f$ : degree of freedom.

\begin{tabular}{ccccc}
\hline & Relative Growth Rate & Performance Index & $\mathbf{F}_{\mathbf{v}} / \mathbf{F}_{\mathbf{0}}$ & $\begin{array}{c}\text { Chlorophyll } \\
\text { Concentration }(\text { Chl) }\end{array}$ \\
\hline Soil type $(d f=2)$ & Fixed Effects $\left(\chi^{\mathbf{2} \text { Values) }}\right.$ & & \\
Irrigation intensity $(d f=4)$ & 5.31 & $306.2^{* * *}$ & $189.9^{* * *}$ & $299.1^{* * *}$ \\
Temperature $(d f=1)$ & 1.71 & $31.6^{* * *}$ & $63.5^{* * *}$ & $65.8^{* * *}$ \\
\hline
\end{tabular}


Table 4. Cont.

\begin{tabular}{|c|c|c|c|c|}
\hline & Relative Growth Rate & Performance Index & $F_{v} / F_{0}$ & $\begin{array}{c}\text { Chlorophyll } \\
\text { Concentration (Chl) }\end{array}$ \\
\hline Vapour pressure deficit $(d f=1)$ & $385.4^{* * *}$ & 0.1 & $11.0^{* * *}$ & $9.1^{* *}$ \\
\hline Soil water potential $(d f=1)$ & $5.7 *$ & $6.3^{*}$ & $6.7^{* *}$ & $31.8^{* * *}$ \\
\hline $\begin{array}{l}\text { Soil type by irrigation intensity } \\
\text { interaction }(d f=8)\end{array}$ & $10.9^{* *}$ & $50.3^{* * *}$ & $115.4^{* * *}$ & $80.7^{* * *}$ \\
\hline Time (week of growth) $(d f=1)$ & $289.4^{* * *}$ & $148.6^{* * *}$ & $289.8^{* * *}$ & $226.1 * * *$ \\
\hline \multicolumn{5}{|c|}{ Random effects (variance) } \\
\hline Tree & 0.20 & 14.61 & 0.47 & 27.14 \\
\hline Residual & 5.72 & 18.55 & 0.13 & 15.18 \\
\hline \multicolumn{5}{|c|}{ Model performance } \\
\hline Conditional pseudo- $R^{2}$ & 0.63 & 0.59 & 0.86 & 0.77 \\
\hline Marginal pseudo- $R^{2}$ & 0.62 & 0.34 & 0.53 & 0.47 \\
\hline $\begin{array}{l}\text { Model significance (likelihood ratio, } \\
\quad p \text {-value) }\end{array}$ & $<0.001$ & $<0.001$ & $<0.001$ & $<0.001$ \\
\hline
\end{tabular}

\subsection{Photosynthetic Activity}

The studied fluorescence proxies varied in sensitivity to the experimental treatments and environmental factors, as indicated by the strength $\left(\chi^{2}\right.$ value) of their effects (Table 4$)$. The studied proxies were highly sensitive to availability of nutrients (Table 1), as indicated by the highest $\chi^{2}$ values of the individual effect of soil type. The individual effect of IRIN was weaker compared to soil type. The significant interaction between the treatments implied the soil-specific sensitivity of the studied proxies to drought. In contrast to weekly RGR, fluorescence proxies were little affected by VPD, which even lacked an effect on PI. Still, considering that IRIN determined the baseline of $\Psi$ s (Figure 1), the significant effect of $\Psi$ s implied the responsiveness of the proxies, particularly CHL, to short-term fluctuation in soil moisture caused by irrigation and VPD $(0.17 \leq r \leq 0.36)$. The marked effect of the time term indicated intra-annual trends in the responses of the proxies (Table 4), as the influence of precipitation interception accumulated (Figure 1). Nevertheless, the studied proxies exhibited subject-specific variation, as indicted by the relatively high variance related to tree.

The fertility of soil (e.g., C and N; Table 1) had a positive linear effect on the mean values of the studied proxies, concomitantly affecting their intra-annual dynamics and responses to irrigation intensities (Figure 4). On the mineral soils under $0 \%$ IRIN, PI and $\mathrm{F}_{\mathrm{V}} / \mathrm{F}_{0}$ showed a rapid drop three weeks after the start of the experiment, while the reaction of CHL was delayed, indicating a lower sensitivity of the proxy (Figure 4). Such a reaction, however, was not observed on peat. On oligotrophic mineral soil, PI and $\mathrm{F}_{\mathrm{v}} / \mathrm{F}_{0}$ showed limited sensitivity to the non-zero irrigation intensities (Figure 4D,G), yet CHL was more sensitive, showing consistent differences throughout the analysed period (Figure 4J). Higher CHL was observed under $25 \%$ and $50 \%$, and the lowest CHL was observed under $75 \%$ and $100 \%$ irrigation intensities, suggesting compensatory effects.

On mesotrophic soil (Figure 4K), CHL showed a similar pattern, yet the differences were weaker, suggesting lower sensitivity to soil moisture. The PI and particularly $\mathrm{F}_{\mathrm{v}} / \mathrm{F}_{0}$ appeared more sensitive to the non-zero irrigation intensities during most of the period (Figure $4 \mathrm{E}, \mathrm{H}$ ), showing the highest values under $50 \%$ and $75 \%$, yet the lowest values under $25 \%$ and $100 \%$ irrigation intensities. Still, on mesotrophic soil, the studied proxies showed increases with time, though the opposite was observed on oligotrophic soil. Higher values of all proxies occurred under the control treatment, particularly in the later part of the experiment (Figure 4E,H,K).

On peat soil, the mean values of the studied proxies where the highest, yet their sensitivity to IRIN was lower than on mesotrophic mineral soil (Table 4). The temporal trends of the photosynthetic proxies were affected by IRIN (Figure 4F,I,L). Under the highest irrigation $(75 \%$ and $100 \%), \mathrm{F}_{\mathrm{V}} / \mathrm{F}_{0}$ and particularly PI showed an increase, while 
under low irrigation ( $0 \%$ and $25 \%$ ), a decrease was observed. This led to a gradual shift in the proportionality between the proxies and irrigation intensities, indicating a magnitudedependent reaction of photosynthetic activity to soil water deficit on peat as the season advanced. Accordingly, the differences in PI and $F_{v} / F_{0}$ among the irrigation intensities were significant during most of the period. Still, CHL showed only slight differences at the beginning and end of the experiment, indicating low sensitivity to soil water deficit on organic soil.

\section{Discussion}

\subsection{Sensitivity of Height Growth}

The studied Norway spruce seedlings from the eastern Baltic provenance region (western Latvia) were tolerant and highly plastic to water deficit in terms of growth and photosynthesis (Figures 3 and 4), confirming the adaptability of the local (meta)populations to harsh conditions [26]. However, seedlings were not able to survive an extended period of extreme drought, as in the case of $0 \%$ IRIN on mineral soils (Figure 1 C,D), when the permanent wilting point was approached [11]. Furthermore, soil type modulated the responses of the total relative increment and fluorescence proxies of saplings to water deficit (Tables 2 and 4). Accordingly, soil appeared to be a key factor determining the sensitivity of the seedlings to water deficit (Table 4). The effect of soil type can be explained both by the differences in water-bearing capacity and fertility [51], and hence the overall vigour of trees and their ability to deal with carbon starvation and dehydration [11,23,24]. This highlights the importance of edaphic conditions on tree sensitivity to weather fluctuations under changing climatic conditions [27,52].

Growth of the studied seedlings showed a plastic response to soil fertility and IRIN (Figures 2 and $4 \mathrm{~A}-\mathrm{C}$ ), implying phenotypical and ecological plasticity, and hence the high adaptability of the trees $[17,26]$. Atmospheric VPD, and hence water deficit, had the strongest effect on weekly RGR on mesotrophic soil (Figure 4A-C; Table 4), indicating increased sensitivity of the trees to water deficit under productive conditions due to highly plastic, and therefore sustainable, growth [52], thus supporting the hypothesis of the study. However, considering that precipitation manipulation subjected seedlings to soil water deficit (compared to the control) (Figure 1), the bell-shaped responses of the total relative increment, which were also modulated by soil type (Figure 2; Table 2), were somewhat surprising. Such responses might be explained by the trade-offs in biomass allocation under water deficit [12,13].

On the mineral soils, which have lower water-bearing capacity compared to peat, higher relative increment formed in response to intermediate IRIN (Figure 2), suggesting that moderate water deficit facilitated growth, and hence competitiveness for light, probably compensating the limited plasticity of root growth [13]. Likewise, the lower increment under the $100 \%$ irrigation might be related to a lack of stimulus for growth, as also evidenced by the intermediate photosynthetic activity (Figure 4G,H). The decreased increment under the $0 \%$ IRIN (Figure 2), however, can be explained by an earlier cessation of growth under severe water deficit (Figures $3 \mathrm{~B}$ and $4 \mathrm{~A}-\mathrm{C}$ ). On peat soil, water deficit progressed considerably slower than on mineral soil (Figure 1C-E), hence the inverse reaction of increment to IRIN (Figure 2) might be explained by the stimulating effect of an intermediate water deficit, which was reached under the $0 \%$ and $25 \%$ treatments. Alternatively, the modulating effect of soil on sensitivity to water deficit (Figures 2 and 4) might be related to changes in soil acidity and mycorrhizal communities [53,54].

The intra-annual growth dynamics (Figures 3 and $4 \mathrm{~A}-\mathrm{C}$ ) suggested diverse pathways of growth adjustments in response to water deficit according to soil type, highlighting the genotype-by-environment interactions and hence phenotypical plasticity of the studied (meta)population [26], supporting the hypothesis of the study. This was particularly evident for the $k$ (i.e., growth cessation rate) parameter of the fitted logistic function (Figure 3C), which appeared soil-specifically affected by irrigation (Table 3). On oligotrophic mineral soils, water deficit caused a rapid drop in weekly RGR, as indicated by the inverse rela- 
tionships between $k$ and IRIN (Figure 3C), following the differences in $\Psi$ s (Figure 1C), thus implying the rapid reaction of growth. In contrast, on peat, $k$ was the lowest, yet little affected by IRIN; additionally, the fastest drop in RGR occurred under intermediate irrigation (Figure 3C), implying a drought-buffering effect of the substrate [51]. On mesotrophic mineral soil, the drop in weekly RGR was the fastest, and it followed IRIN, confirming the plasticity of the trees to drought on fertile soils [52].

Irrespective of soil type, IRIN had a consistent effect on the $\beta$ parameter (Figure 3B, Table 3), indicating that water deficit caused an earlier cessation of growth, thus optimizing the usage of the intrinsic reserves of trees $[5,12,23]$. The $\alpha$ parameter (Figure 3A), which represents the maximum RGR, however, was not affected by the treatments (Table 3), as it was related to growth in the beginning of the experiment (Figure $4 \mathrm{~A}-\mathrm{C}$ ), when $\Psi \mathrm{s}$ was still high (Figure 1C-E). Such growth patterns suggest that a shorter period of faster growth is an adaptation for minimizing the long-term effect of a short-term summer water deficit [23,52].

\subsection{Photosynthetic Performance}

Mean values and temporal changes of the florescence proxies PI and $F_{v} / F_{0}$ suggested the photosynthetic plasticity of Norway spruce seedlings to water deficit across the soil fertility gradient. Although $\mathrm{F}_{\mathrm{v}} / \mathrm{F}_{0}$ and, particularly, PI are limited to comparisons of different states of the same plant [36], the application of mixed effects models (accounting for the random effect of trees) allowed for the generalization of the effects of treatments on the photosynthetic performance of the seedlings. The individuality of responses evidenced by the random effect (Table 4) was likely due to open-pollinated seed material $[26,35,55]$.

In contrast to growth, the studied fluorescence proxies were mainly affected by soil type (Table 4, Figure 4), thus being indicative of the productivity and vigour of the seedlings $[11,23,24]$. Nevertheless, soil modulated the sensitivity of the photosynthetic activity of the seedlings to IRIN (Table 4), thus highlighting complex controls of photosynthesis by water deficit across the soil fertility gradient [27,42,51]. Still, the strength of the individual effect of IRIN differed by proxies, indicating differences in their sensitivity to water deficit for Norway spruce $[5,36,43]$. This also illustrated the phenotypic plasticity of the photosynthetic apparatus of the studied Norway spruce [5], implying their adaptability to changing environmental conditions $[17,35,56]$. The plasticity of the studied (meta)population of Norway spruce to water deficit might be explained by its location in the southern part of the North European population [55], and hence a potential genetic adaptation to soil water deficit $[17,44,56]$.

The hypothesis of the study, however, was not confirmed completely, as sensitivity of the fluorescence proxies to water deficit (IRIN) differed according to soil type (Table 4; Figure $4 \mathrm{D}-\mathrm{L}$ ). On mineral soils, $\mathrm{PI}$ and $\mathrm{F}_{\mathrm{v}} / \mathrm{F}_{0}$ were particularly sensitive to severe water deficit ( $0 \%$ IRIN), which eventually led to the collapse of photochemical reactions [25,33,41], and death of the seedlings. Decreases in CHL, however, were delayed and occurred when PI and $F_{v} / F_{0}$ reached their minimum (Figure $4 \mathrm{D}-\mathrm{L}$ ), likely indicating severe structural damage [43], thus implying highly plastic regulation of photosynthesis to avoid fatal failure $[5,24,41,57]$. The differences in timing also implied potential for early warning of upcoming irreversible damage based on easily measurable variables $[30,36,43]$. On peat soil, however, explicit reaction was not apparent to $0 \%$ IRIN, as severe soil water deficit occurred only for a short period at the end of the experiment (Figure 1E), when growth had ceased (Figure 4C), likely allowing seedlings to compensate for damages [24,37,40]. Considering that precipitation manipulation was initiated when the growth peaked (Figure $4 \mathrm{~A}-\mathrm{C}$ ), earlier drought and hence a longer period of water deficit would likely cause harsher consequences on photosynthesis and growth $[33,38]$.

The PI, which has been shown as being a highly sensitive indicator of suboptimal conditions [43], showed limited sensitivity to the non-zero IRIN on oligotrophic mineral soil (Figure 4), likely due to stronger constraints of photosynthesis $[5,24]$. The CHL was more sensitive to IRIN than PI and $F_{v} / F_{0}$ (Figure $\left.4 D, G, J\right)$ ), suggesting that under harsher 
conditions the CHL was constrained for optimization of the photosynthetic performance in the long term $[38,41,58]$. Still, on mesotrophic mineral soil, PI and $F_{v} / F_{0}$ were more sensitive to IRIN than CHL (Figure 4), indicating the plasticity of the regulatory mechanisms under more productive conditions [36,41,43,59].

Similarly to relative height increment (Figure 2), the highest photosynthetic activity, as shown by PI and $F_{v} / F_{0}$, occurred under intermediate IRIN on mineral soil and under the lowest IRIN on peat (Figure 4D-I), implying that under moderate water deficit photosynthesis is optimized to avoid oxidative stress, as well as carbon starvation [24]. Such optimization was particularly evident on oligotrophic mineral soil, where CHL was increased, likely to counteract increasing water deficit $[35,58]$. On peat soil, a similar effect was observed at the beginning of the experiment, yet IRIN had a positive influence on photosynthetic performance (Figure 4) towards the end of the experiment as water deficit increased (Figure 1), implying that the slowed drying out of peat soil apparently provided more time for seedings to adjust to water deficit [37].

Irrespective of soil and IRIN, PI and $\mathrm{F}_{\mathrm{v}} / \mathrm{F}_{0}$ showed rapid and successful recovery of photosynthetic activity, which ultimately reached initial levels (Figure 4), implying the high plasticity and sustainability of the studied Norway spruce to water deficit $[18,25,59]$. This, apparently, was gained at the cost of growth $[12,16]$ and adjusted physiological performance $[5,24,57]$. Accordingly, this enabled the seedlings to restore lignification of xylem and nutrient reserves, likely minimizing the impact of drought on the following growth $[14,15]$. The recovery of seedlings after the rewatering in August 20, however, was best evidenced by $\mathrm{F}_{\mathrm{v}} / \mathrm{F}_{0}$, and PI (Figure $4 \mathrm{D}-\mathrm{I}$ ), suggesting immediacy, and hence relevance of the first. In contrast, the reaction of $\mathrm{CHL}$ in response to rewatering was not observed, as a longer time and additional nutrients are necessary for plants to adjust their photosynthetic apparatus [58].

The complexity of the responses of fluorescence proxies to IRIN and soil, however, imply reduced efficiency for remote sensing purposes, as additional site factors have to be accounted for [29,31,34]. Still, the physiology of trees is influenced by their size/age [13], implying that changes in such reactions of trees are expected. Also, the mortality of Norway spruce following droughts is often caused by secondary biotic agents (e.g., pests), which take advantage of weakened trees [21,22], implying age/size-related changes in the susceptibility of trees. A wider provenance-wise comparison might also provide better insight in the genetic specialization of tree populations within the region.

\section{Conclusions}

Norway spruce seedlings from the eastern Baltic provenance region showed high adaptability to drought in the second part of the growing period, as evidenced by highly plastic responses regarding growth and photosynthetic activity, thus suggesting fitness to projected climatic conditions. Nevertheless, the plasticity of the responses was modulated by soil, implying the importance of the edaphic conditions for the sustainability of the early growth of Norway spruce under acceleratingly changing climate. Accordingly, considering the projected intensification of soil water deficit in summer, peat soils, which have the highest water-bearing capacity, appear advantageous for Norway spruce, while on mineral soils, trees are susceptible to water deficit. Such relationships, however, might shift as trees age due to size-dependant changes in physiological processes. The efficiency of the chlorophyll fluorescence proxies for early warming of drought-related damages of young Norway spruce appears limited due to the complexity of responses to water deficit across the fertility gradient and plastic regulation of photosynthesis. Nevertheless, $\mathrm{F}_{\mathrm{v}} / \mathrm{F}_{0}$, and PI can provide early warming of severe damage. Although growth reduction appeared more sensitive, it is relative, and hence difficult to assess in field conditions.

Author Contributions: Conceptualization: R.M., O.K., and Ā.J.; Methodology: R.M. and G.I.; Software: O.K., and T.K.; Validation: G.I. and D.E.; Formal Analysis: D.E.; Investigation: R.M., O.K., T.K., and G.I.; Resources: Ā.J.; Data Curation: O.K.; Writing-Original Draft Preparation: R.M. and G.I.; Writing-Review and Editing: R.M. and A..J.; Visualization: R.M. and D.E.; Supervision: Ā.J., and 
G.I.; Project Administration: Ā.J.; Funding Acquisition: Ā.J. All authors have read and agreed to the published version of the manuscript.

Funding: This research was funded by the European Regional Development Fund, grant numbers 1.1.1.2.VIAA/1/16/108 and 1.2.1.1/18/A/004.

Institutional Review Board Statement: Not applicable.

Informed Consent Statement: Not applicable.

Data Availability Statement: Data sharing not applicable.

Acknowledgments: The study was finalized and the manuscript prepared under the framework of the post-doctoral studies in Latvia ('Plasticity of development and xylogenesis of the native and introduced tree species under changing climate', project No.: 1.1.1.2.VIAA/1/16/108) financed by the European Regional Development Fund. Collection of data was funded by the Forest Competence Centre (ERDF) project "Technology for early diagnostics of genetically determined variation of resilience-related trait for Norway spruce" (1.2.1.1/18/A/004).

Conflicts of Interest: The authors declare no conflict of interests.

\section{References}

1. Buras, A.; Menzel, A. Projecting tree species composition changes of European forests for 2061-2090 under RCP 4.5 and RCP 8.5 scenarios. Front. Plant. Sci. 2019, 9, N1986. [CrossRef]

2. Hanewinkel, M.; Cullmann, D.A.; Schelhaas, M.J.; Nabuurs, G.J. Climate change may cause severe loss in the economic value of European forest land. Nat. Clim Chang. 2012, 3, 203-207. [CrossRef]

3. Nabuurs, G.J.; Verkerk, P.J.; Schelhaas, M.J.; González Olabarria, J.R.; Trasobares, A.; Cienciala, E. Climate-Smart Forestry: Mitigation Impacts in Three European Regions — Science to Policy 6; European Forest Institute: Vienna, Austria, 2018.

4. Taeger, S.; Zang, C.; Liesebach, M.; Schneck, V.; Menzel, A. Impact of climate and drought events on the growth of Scots pine (Pinus sylvestris L.) provenances. For. Ecol. Manag. 2013, 307, 30-42. [CrossRef]

5. Ditmarova, L.; Kurjak, D.; Palmroth, S.; Kmet, J.; Střelcová, K. Physiological responses of Norway spruce (Picea abies) seedlings to drought stress. Tree Physiol. 2009, 30, 205-213. [CrossRef]

6. Thurm, E.A.; Hernandez, L.; Baltensweiler, A.; Ayan, S.; Rasztovits, E.; Hernández, L.; Zlatanov, T.M.; Hladnik, D.; Bielak, K.; Freudenschuss, A.; et al. Alternative tree species under climate warming in managed European forests. For. Ecol. Manag. 2018, 430, 485-497. [CrossRef]

7. Lindner, M.; Maroschek, M.; Netherer, S.; Kremer, A.; Barbati, A.; García-Gonzalo, J.; Seidl, R.; Delzon, S.; Corona, P.; Kolström, M.; et al. Climate change impacts, adaptive capacity, and vulnerability of European forest ecosystems. For. Ecol. Manag. 2010, 259, 698-709. [CrossRef]

8. Trajkovic, S. Temperature-based approaches for estimating reference evapotranspiration. J. Irrig. Drain. Eng. 2005, 131, 316-323. [CrossRef]

9. Intergovernmental Panel on Climate Change. Climate Change 2013-The Physical Science Basis: Working Group I Contribution to the Fifth Assessment Report of the Intergovernmental Panel on Climate Change; Cambridge University Press: Cambridge, UK, 2014. [CrossRef]

10. Harvey, J.E.; Smiljanić, M.; Scharnweber, T.; Buras, A.; Cedro, A.; Cruz-García, R.; Drobyshev, I.; Janecka, K.; Jansons, Ā.; Kaczka, R.; et al. Tree growth influenced by warming winter climate and summer moisture availability in northern temperate forests. Glob. Chang. Biol. 2020, 26, 2505-2518. [CrossRef]

11. Allen, C.D.; Macalady, A.K.; Chenchouni, H.; Bachelet, D.; McDowell, N.; Vennetier, M.; Kitzberger, T.; Rigling, A.; Breshears, D.D.; Hogg, E.H.T.; et al. A global overview of drought and heat-induced tree mortality reveals emerging climate change risks for forests. For. Ecol. Manag. 2010, 259, 660-684. [CrossRef]

12. Brunner, I.; Herzog, C.; Dawes, M.A.; Arend, M.; Sperisen, C. How tree roots respond to drought. Front. Plant. Sci. 2015, 6, N547. [CrossRef]

13. Schall, P.; Lödige, C.; Beck, M.; Ammer, C. Biomass allocation to roots and shoots is more sensitive to shade and drought in European beech than in Norway spruce seedlings. For. Ecol. Manag. 2012, 266, 246-253. [CrossRef]

14. Jyske, T.; Holtta, T.; Mäkinen, H.; Nojd, P.; Lumme, I.; Spiecker, H. The effect of artificially induced drought on radial increment and wood properties of Norway spruce. Tree Physiol. 2009, 30, 103-115. [CrossRef]

15. Cuny, H.E.; Rathgeber, C.B.; Frank, D.; Fonti, P.; Mäkinen, H.; Prislan, P.; Rossi, S.; Del Castillo, E.M.; Campelo, F.; Vavrčík, H.; et al. Woody biomass production lags stem-girth increase by over one month in coniferous forests. Nat. Plants. 2015, 1, 1-6. [CrossRef]

16. Mäkinen, H.; Nojd, P.; Saranpaa, P. Seasonal changes in stem radius and production of new tracheids in Norway spruce. Tree Physiol. 2003, 23, 959-968. [CrossRef]

17. Moran, E.; Lauder, J.; Musser, C.; Stathos, A.; Shu, M. The genetics of drought tolerance in conifers. New Phytol. 2017, 216, 1034-1048. [CrossRef]

18. Possen, B.J.H.M.; Oksanen, E.; Rousi, M.; Ruhanen, H.; Ahonen, V.; Tervahauta, A.I.; Heinonen, J.; Heiskanen, J.; Kärenlampi, S.; Vapaavuori, E. Adaptability of birch (Betula pendula Roth) and aspen (Populus tremula L.) genotypes to different soil moisture conditions. For. Ecol. Manag. 2011, 262, 1387-1399. [CrossRef] 
19. Jansons, Ā.; Matisons, R.; Šēnhofa, S.; Katrevičs, J.; Jansons, J. High-frequency variation of tree-ring width of some native and alien tree species in Latvia during the period 1965-2009. Dendrochronologia 2016, 40, 151-158. [CrossRef]

20. Schlyter, P.; Stjernquist, I.; Bärring, L.; Jönsson, A.M.; Nilsson, C. Assessment of the impacts of climate change and weather extremes on boreal forests in northern Europe, focusing on Norway spruce. Clim. Res. 2006, 31, 75-84. [CrossRef]

21. Netherer, S.; Panassiti, B.; Pennerstorfer, J.; Matthews, B. Acute drought is an important driver of bark beetle infestation in Austrian Norway spruce stands. Front. For. Glob. Change 2019, 2, N39. [CrossRef]

22. Jönsson, A.M.; Appelberg, G.; Harding, S.; Bärring, L. Spatio-temporal impact of climate change on the activity and voltinism of the spruce bark beetle, Ips typographus. Glob. Chang. Biol. 2009, 15, 486-499. [CrossRef]

23. Breda, N.; Huc, R.; Granier, A.; Dreyer, E. Temperate forest trees and stands under severe drought: A review of ecophysiological responses, adaptation process and long-term consequences. Ann. For. Sci. 2006, 63, 625-644. [CrossRef]

24. Hartmann, H.; Ziegler, W.; Kolle, O.; Trumbore, S. Thirst beats hunger-declining hydration during drought prevents carbon starvation in Norway spruce saplings. New Phytol. 2013, 200, 340-349. [CrossRef] [PubMed]

25. Xu, Z.; Zhou, G.; Shimizu, H. Plant responses to drought and rewatering. Plant. Signal. Behav. 2010, 5, 649-654. [CrossRef] [PubMed]

26. Suvanto, S.; Nöjd, P.; Henttonen, H.M.; Beuker, E.; Mäkinen, H. Geographical patterns in the radial growth response of Norway spruce provenances to climatic variation. Agric For. Meteorol. 2016, 222, 10-20. [CrossRef]

27. Rehschuh, R.; Mette, T.; Menzel, A.; Buras, A. Soil properties affect the drought susceptibility of Norway spruce. Dendrochronologia 2017, 45, 81-89. [CrossRef]

28. Trumbore, S.; Brando, P.; Hartmann, H. Forest health and global change. Science 2015, 349, 814-818. [CrossRef]

29. Prabhakar, M.; Prasad, Y.G.; Rao, M.N. Remote sensing of biotic stress in crop plants and its applications for pest management. In Crop Stress and Its Management: Perspectives and Strategies; Venkateswarlu, B., Shanker, A.K., Shanker, C., Maheswari, M., Eds.; Springer: New York, NY, USA, 2012; pp. 517-549.

30. Eitel, J.U.H.; Vierling, L.A.; Litvak, M.E.; Long, D.S.; Schulthess, U.; Ager, A.A.; Krofcheck, D.J.; Stoscheck, L. Broadband, red-edge information from satellites improves early stress detection in a New Mexico conifer woodland. Remote Sens. Environ. 2011, 115, 3640-3646. [CrossRef]

31. Lausch, A.; Borg, E.; Bumberger, J.; Dietrich, P.; Heurich, M.; Huth, A.; Jung, A.; Klenke, R.A.; Knapp, S.; Mollenhauer, H.; et al. Understanding forest health with remote sensing, part III: Requirements for a scalable multi-source forest health monitoring network based on data science approaches. Remote Sens. 2018, 10, 1120. [CrossRef]

32. Malenovský, Z.; Homolová, L.; Zurita-Milla, R.; Lukeš, P.; Kaplan, V.; Hanuš, J.; Gastellu-Etchegorry, J.-P.; Schaepman, M.E. Retrieval of spruce leaf chlorophyll content from airborne image data using continuum removal and radiative transfer. Remote Sens. Environ. 2013, 131, 85-102. [CrossRef]

33. Leuzinger, S.; Zotz, G.; Asshoff, R.; Korner, C. Responses of deciduous forest trees to severe drought in Central Europe. Tree Physiol. 2005, 25, 641-650. [CrossRef]

34. Carter, G.A.; Knapp, A.K. Leaf optical properties in higher plants: Linking spectral characteristics to stress and chlorophyll concentration. Am. J. Bot. 2001, 88, 677-684. [CrossRef] [PubMed]

35. Bigras, F.J. Photosynthetic response of white spruce families to drought stress. New For. 2005, 29, 135-148. [CrossRef]

36. Tsimilli-Michael, M. Revisiting JIP-test: An educative review on concepts, assumptions, approximations, definitions and terminology. Photosynthetica 2020, 58, 275-292. [CrossRef]

37. Kaur, G.; Asthir, B. Molecular responses to drought stress in plants. Biol. Plant. 2017, 61, 201-209. [CrossRef]

38. Fang, Y.; Xiong, L. General mechanisms of drought response and their application in drought resistance improvement in plants. Cell. Mol. Life Sci. 2015, 72, 673-689. [CrossRef]

39. Shanker, A.K.; Maheswari, M.; Yadav, S.K.; Desai, S.; Bhanu, D.; Attal, N.B.; Venkateswarlu, B. Drought stress responses in crops. Funct. Integr. Genomics. 2014, 14, 11-22. [CrossRef] [PubMed]

40. Rao, D.E.; Chaitanya, K.V. Photosynthesis and antioxidative defense mechanisms in deciphering drought stress tolerance of crop plants. Biol. Plant. 2016, 60, 201-218. [CrossRef]

41. Chaves, M.M.; Flexas, J.; Pinheiro, C. Photosynthesis under drought and salt stress: Regulation mechanisms from whole plant to cell. Ann. Bot. 2009, 103, 551-560. [CrossRef]

42. Flexas, J.; Gallé, A.; Galmée, J.; Ribas-Carbo, M.; Medrano, H. The response of photosynthesis to soil water stress. In Plant Responses to Drought Stress; Aroca, R., Ed.; Springer: Berlin/Heidelberg, Germany, 2012; pp. 129-144.

43. Kalaji, H.M.; Carpentier, R.; Allakhverdiev, S.I.; Bosa, K. Fluorescence parameters as early indicators of light stress in barley. J. Photochem. Photobiol. B Biol. 2012, 112, 1-6. [CrossRef]

44. Badr, A.; Brüggemann, W. Comparative analysis of drought stress response of maize genotypes using chlorophyll fluorescence measurements and leaf relative water content. Photosynthetica 2020, 58, 638-645. [CrossRef]

45. Harris, I.P.; Jones, P.D.; Osborn, T.J.; Lister, D.H. Updated high-resolution grids of monthly climatic observations-The CRU TS3. 10 Dataset. Int. J. Climatol. 2014, 34, 623-642. [CrossRef]

46. Bušs, K. Basis of Forest Classification in SSR of Latvia. Latvijas PSR Meža Klasifikācijas Pamati; LRZTIPI: Riga, Latvia, 1976; p. 24. (In Latvian)

47. Stirbet, A.; Govindjee. On the relation between the Kautsky effect (chlorophyll a fluorescence induction) and Photosystem II: Basics and applications of the OJIP fluorescence transient. J. Photochem. Photobiol. B Biol. 2011, 104, 236-257. [CrossRef] [PubMed] 
48. Pommerening, A.; Muszta, A. Methods of modelling relative growth rate. For. Ecosyst. 2015, 2, N5. [CrossRef]

49. R Core Team R: A Language and Environment for Statistical Computing; R Foundation for Statistical Computing: Vienna, Austria, 2020; Available online: https:/ /www.R-project.org/ (accessed on 20 December 2020).

50. Bates, D.; Maechler, M.; Bolker, B.; Walker, S. Fitting Linear Mixed-Effects Models Using lme4. J. Stat. Softw. 2015, 67, 148. [CrossRef]

51. Piedallu, C.; Gégout, J.C.; Bruand, A.; Seynave, I. Mapping soil water holding capacity over large areas to predict potential production of forest stands. Geoderma 2011, 160, 355-366. [CrossRef]

52. Weemstra, M.; Eilmann, B.; Sass-Klaassen, U.G.; Sterck, F.J. Summer droughts limit tree growth across temperate species on a productive forest site. For. Ecol. Manag. 2013, 306, 142-149. [CrossRef]

53. Yang, H.; Yuan, Y.; Zhang, Q.; Tang, J.; Liu, Y.; Chen, X. Changes in soil organic carbon, total nitrogen, and abundance of arbuscular mycorrhizal fungi along a large-scale aridity gradient. Catena 2011, 87, 70-77. [CrossRef]

54. Oehl, F.; Laczko, E.; Bogenrieder, A.; Stahr, K.; Bösch, R.; van der Heijden, M.; Sieverding, E. Soil type and land use intensity determine the composition of arbuscular mycorrhizal fungal communities. Soil Biol. Biochem. 2010, 42, 724-738. [CrossRef]

55. Tollefsrud, M.M.; Kissling, R.; Gugerli, F.; Johnsen, Ø.; Skrøppa, T.; Cheddadi, R.; Van Der Knaap, W.O.; Latałowa, M.; TerhürneBerson, R.; Litt, T.; et al. Genetic consequences of glacial survival and postglacial colonization in Norway spruce: Combined analysis of mitochondrial DNA and fossil pollen. Mol. Ecol. 2008, 17, 4134-4150. [CrossRef]

56. Skrøppa, T.; Tollefsrud, M.M.; Sperisen, C.; Johnsen, Ø. Rapid change in adaptive performance from one generation to the next in Picea abies-Central European trees in a Nordic environment. Tree Genet. Genomes 2010, 6, 93-99. [CrossRef]

57. Pukacki, P.M.; Kamińska-Rożek, E. Effect of drought stress on chlorophyll a fluorescence and electrical admittance of shoots in Norway spruce seedlings. Trees 2005, 19, 539-544. [CrossRef]

58. Anderson, J.M.; Chow, W.S.; Park, Y.I. The grand design of photosynthesis: Acclimation of the photosynthetic apparatus to environmental cues. Photosyn. Res. 1995, 46, 129-139. [CrossRef] [PubMed]

59. Iivonen, S.; Kaakinen, S.; Jolkkonen, A.; Vapaavuori, E.; Linder, S. Influence of long-term nutrient optimization on biomass, carbon, and nitrogen acquisition and allocation in Norway spruce. Can. J. For. Res. 2006, 36, 1563-1571. [CrossRef] 